\title{
DEVELOPMENT OF SCIENCE INTERACTIVE STUDENT WORKSHEETS ORIENTED HIGHER- ORDER THINKING SKILLS FOR ELEMENTARY SCHOOL STUDENT
}

\author{
Baiq Niswatul Khair, Muhammad Makki, Fitri Puji Astria, Muhammad Erfan, and Hasnawati \\ Elementary School Teacher Study Program, Faculty of Teacher Training and Education, University of Mataram, \\ Mataram, Indonesia \\ *Email: baiqniswatul_fkip@unram.ac.id
}

\author{
Accepted: January 08, 2022. Approved: January 10, 2022. Published: January 15, 2022
}

\begin{abstract}
This research aims to develop science interactive students' worksheets oriented to higher-order thinking skills for the fifth elementary school students. The developed student worksheet aims to provoke and familiarize students with their higher-order thinking ability. The cognitive domain of higher-order thinking skills involved is analytical skills. The 4D development model (define, design, develop, and disseminate) was used in this study. The data in this study were collected using a validation sheet. Data analysis was carried out in a quantitative descriptive. The development results showed that science interactive students worksheets oriented to higher-order thinking skills developed were valid with an average score of 3.33. Secondly, the score for the practicality of using the science interactive students' worksheets was 3.69 and 3.38 according to teachers and students, respectively. In conclusion, the science interactive students' worksheets oriented towards higher-order thinking skills, are valid and practical to be used by students of the fifth-grade elementary school.
\end{abstract}

Keywords: Science, Liveworksheets, Elementary Education

\section{INTRODUCTION}

Education in the $21^{\text {st }}$ century or independent learning is characterized by four main paradigms: information, computing, automation, and communication. In the information paradigm, educators encourage students to learn from various sources of observation, not just relying on their educator or waiting to be told. In the computational paradigm, learning is directed to formulate problems (asking the question themselves), not just solve problems (answering the problem). In the automation paradigm, learning is directed to train students to think critically and analytically (in decision making), not only think mechanism (routine). While at the point of communication, learning emphasizes the importance of cooperation and collaboration in solving problems [1]. From the description of the issues of the learning paradigm in the $21^{\text {st }}$ century, it can be seen that most of them focus more on mastering critical thinking skills and higher-order thinking skills (HOTS) [2-6].

Based on PISA results in 2012, education outcomes in Indonesia still need improvement. It can be seen from the 65 member countries of PISA, Indonesia is ranked $64^{\text {th }}$ or number two from the bottom. The results of the PISA survey in 2015 did not change Indonesia's position, namely at position 64 out of 72 PISA member countries. In 2018, Indonesia's position declined from 64 to 70 out of 78 countries [711]. This result is, of course, contrary to the frequent occurrence of several students from Indonesia who won the International Science Olympiad in Physics.

PISA questions measure scientific literacy, numeracy, language, and economics, which most students in Indonesia have difficulty with because generally, students in schools are only taught memory skills based on Bloom's Taxonomy and are only included in low-level thinking skills (LOTS) [12-16].
Coupled with the pandemic that has changed the order and pattern of life, students must adapt quickly, and educators must be ready for all the challenges and changes that require everyone to have an attitude of learning. Educators need to find out about what strategies and what teaching materials are suitable to foster the attitude and curiosity of students so that students become fond of learning without being given pressure or assignments.

Based on the description above, we need an appropriate way to improve students' thinking skills from previously only being able to think at low levels (LOTS) to feel at high levels (HOTS). The vital role of teaching materials must and must be developed by educators. The learning process assists educators in directing learning so that it can run optimally. In the long term, the four learning paradigms can be mastered in the era of Merdeka belajar [16-19].

One teaching material that can facilitate students in learning activities in class and independent learning is student worksheets [20]. Every educator must develop their student worksheets as one of the media and teaching materials according to the characteristics of students in learning [21-23]. Student worksheets must be in accordance with the aspects of students because in the learning process, what is seen, felt, and experienced by each is different according to the situation, condition, and state of the environment where the student lives [24-25]. In addition, the developed student worksheets are also based on the needs or learning settings themselves.

Referring to the learning conditions during the COVID-19 pandemic, fifth-grade students at State Elementary School 6 Mataram are currently studying online. The online mechanism referred to here is that students learn at home through various online platforms such as Whatsapp, Google classroom, 
Zoom, etc. This condition is a consideration for educators and researchers to develop teaching materials in suitable and feasible student worksheets. Suitability, in this case, refers to the suitability of teaching materials with learning objectives, student characteristics, and student learning environment. The feasibility here refers to validity and practicality when used in the learning process. Valid means measuring or conveying according to what must be conveyed, practical means easy to use, and has a good effect on learning objectives.

One platform that can allow students to work on worksheets live is live worksheets. The Liveworksheets platform is an application that can convert traditional printable worksheets (documents, pdf, and jpg) into interactive online exercises because they can contain videos, images, and audio [26]. Live worksheets have more effective text, images, animations, videos to make learning more exciting, and students don't get bored quickly [27]. Based on this, researchers are interested in developing a Science Liveworksheet oriented to higher-order thinking skills (HOTS) for fifth-grade elementary school students.

\section{RESEARCH METHOD}

This research is a research and development (R\&D). The development model used was 4-D which consists of four stages, namely: (1) Define; (2) Design; (3) Develop; and (4) Disseminate [28-30]. The Define stage aims to identify and define the requirements needed and will be presented in interactive science worksheets in the development process. The instruments used in the define stage are observation sheets, interview sheets, and elementary school curriculum studies. The Design stage, which is the next stage of the Define stage, is more focused on designing LKPD based on the initial investigations carried out at the Define stage. The Develop stage, which is the development stage, aims to produce live science worksheets oriented towards higher-order thinking skills (HOTS) suitable for the next step (dissemination). The Disseminate stage, which was the final stage, is carried out through seminars, publication of research articles, submission of intellectual property rights (IPR), and product dissemination to partner schools, in this case, State Elementary School 6 Mataram.

The instrument used in the data collection process in this study was an expert validation questionnaire sheet. The expert validation sheet is used to determine the feasibility of the interactive science student worksheets that have been developed. After the experts declared the interactive science worksheets feasible and valid, the media was tested. The trial was carried out on students at State Elementary School 6 Mataram, where one of the educators from the school was also accustomed to using Liveworksheets as a means of teaching material that required worksheets for students.

The research data were analyzed descriptively and quantitatively. The feasibility test was assessed for student questionnaires and expert validation questionnaires using a Likert scale with a maximum score of 4 (four). The total score obtained from the assessment is then calculated as the total value of each aspect of the entire respondent. Respondents in this study were one expert, one educator, and several students as small groups. After the total value is obtained, the media feasibility range is made qualitatively. The criteria for assessing the validity of the developed LKPD are presented in Table 1.

Table 1. Student worksheet validity criteria

\begin{tabular}{ll}
\hline Score & Criteria \\
\hline $3,5<\mathrm{SR} \leq 4,0$ & Very Valid \\
$2,5<\mathrm{SR} \leq 3,5$ & Valid \\
$1,5<\mathrm{SR} \leq 2,5$ & Invalid \\
$1,0<\mathrm{SR} \leq 1,5$ & Very Invalid \\
\hline
\end{tabular}

In addition to the validity test of the student's worksheets, the practicality test of the interactive Science student's worksheets was also carried out with the applicable criteria of the interactive student's worksheets oriented to higher-order thinking skills (HOTS) which is presented in Table 2.

Table 2. Student worksheet practical criteria

\begin{tabular}{ll}
\hline Score & Criteria \\
\hline $3,5<\mathrm{SR} \leq 4,0$ & Very Practical \\
$2,5<\mathrm{SR} \leq 3,5$ & Practical \\
$1,5<\mathrm{SR} \leq 2,5$ & Not Practical \\
$1,0<\mathrm{SR} \leq 1,5$ & Very Impractical \\
\hline
\end{tabular}

\section{RESULT AND DISCUSSION}

\section{Preview of Developed Interactive Science} Liveworksheets

One indicator of the ability to analyze (included in higher-order thinking skills) is to differentiate. This ability includes distinguishing between facts and opinions and using the information to solve problems presented in questions on student worksheets, as shown in Figure 1.

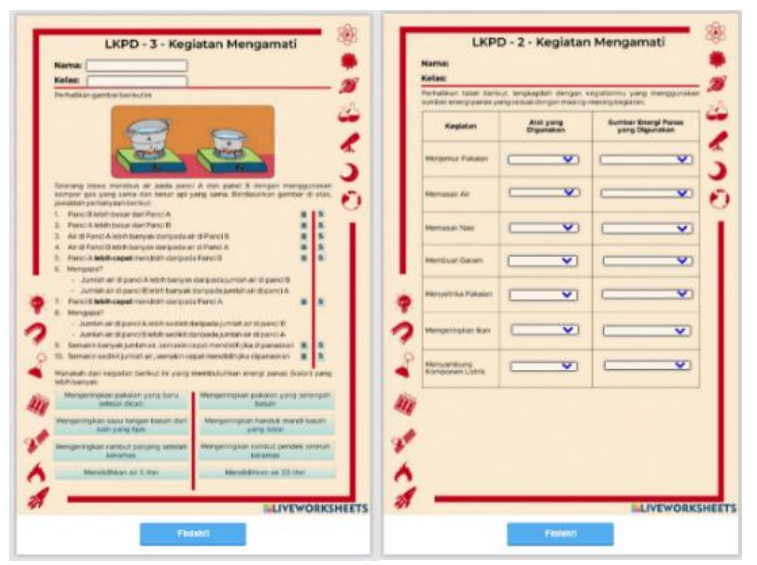

Figure 1. Activities carried out on Interactive Science Liveworksheets 


\section{Define Stage}

The analysis carried out at this stage consists of five main steps: problem analysis, student analysis, concept analysis, task analysis, and formulation of learning objectives.

The problem analysis carried out in this stage is to conduct interviews with educators at State Elementary School 6 Mataram to obtain information about the facts, conditions, and obstacles educators face in teaching science (Science) in elementary schools, especially at State Elementary School 6 Mataram. The information obtained is used to analyze problems that arise in learning science in elementary school grade V (five). After conducting interviews with educators and learning observations, it was found that several problems could be defined in science learning in elementary schools. Students' involvement, especially during online learning, during the pandemic, was generally low, so students tended to be passive. The development of students' higherorder thinking skills is still lacking, especially for class $\mathrm{V}$ (five) students on the theme of heat and its displacement. The teaching materials used still involve more textbooks, and the worksheets used are still contained in the books so that students are not accustomed to solving problems that require higherorder thinking skills. The learning method used is still dominated by conventional methods or lectures, which are more teacher-centered. These problems are the basis for determining what will be presented and developed in the Interactive Science Liveworksheets, oriented to higher-order thinking skills (HOTS) so that student worksheets can be more effective and efficient.

Interviews carried out the analysis of the students. In the discussions conducted, it was found that most of the students, especially in class V (five), had been well facilitated in terms of online learning or learning involving computer networks and the internet. According to digital literacy educators, the motivation of class V (five) students at State Elementary School 6 Mataram can be considered relatively high in participating in learning activities. Students in class V (five) can be categorized as adequate, considering that these students were born as digital natives. Some of these facts can be used as a reference for developing Interactive Science LKPD oriented to higher-order thinking skills (HOTS), which can trigger students to apply higher-order thinking skills in solving various problems.

Concept analysis, which identifies the main concepts to be taught, must be arranged in a systematic and detailed manner. The concepts related to the core competencies and basic competencies chosen are the source of heat energy and the length of heating time. Prioritizes the understanding that the greater the volume of a liquid whose temperature is raised, the greater the amount of heat required, and the longer the liquid's drying time or evaporation time.

Task analysis is more directed at achieving the competencies taught in the learning process. The competencies developed are based on the fifth-grade elementary school curriculum, namely applying the concept of heat transfer in everyday life.

Formulation of learning objectives is designed Interactive Science Liveworksheets. Learning objectives based on core competencies and basic competencies used include identifying sources of heat energy used in daily life, identifying daily activities that use heat energy, and applying the concept of heat transfer in everyday life.

\section{Design Stage}

The Design stage is focused on designing the Interactive Science Liveworksheets design. The components at the initial design stage of student worksheets oriented to higher-order thinking skills (HOTS) are reading activities that students can carry out. There are interactive questions that familiarize students with higher-order thinking in answering questions.

\section{Development Stage}

The development stage aims to produce better learning tools after going through various validation processes, both media, and material experts. The Interactive Science Leveworksheets, which had gone through the validation process was, then tested on a limited basis to some elementary school students at State Elementary School 6 Mataram to find out the practicality of the Interactive Science Liveworksheets that had been developed.

\section{Validity}

The validation process involves two validators, namely the material expert validator and the media expert validator. The validator validates the correctness of the content, the suitability of the content of the material with core competencies and basic competencies, checks the LKPD format, examines linguistic aspects, and sees and provides input related to the graphic of the Interactive Science LKPD developed by the researcher. The technical assessment given by the validator is to fill out a questionnaire and ask for opinions, criticisms, and suggestions for improvement. The questionnaire is filled out by putting a checklist $(\sqrt{ })$ in the column corresponding to the assessment given. The highest score is four, and the lowest is 1 for each question or statement intended for experts. The total score given by the validator is then averaged and then compared with a scale value of 4. The provisions and procedures for this assessment apply to all data from the validation results. The recapitulation of the validation results of the developed Interactive Science Liveworksheets is presented in Table 3.

The overall expert validation test results show valid results with a final score of 3.33. Some notes given by the validator are: 1 ) increasing the number of pictures on the Interactive Science Liveworksheets, 2) increasing the variety of types of questions that are 
more for analytical abilities (C4), and 3) The answer options for questions are made more varied.

Table 3. The average score of validation assessment

\begin{tabular}{lcc}
\hline Assessment Aspect & Mean & Category \\
\hline Content & 3,20 & Valid \\
Language & 3,40 & Valid \\
Graphics & 3,50 & Valid \\
\hline
\end{tabular}

\section{Practicality}

The practicality data of the product trial consists of data on the response of educators to the suitability of the material content, structure, and language used in the Interactive Science Liveworksheets on heat and its transfer material, as well as student responses to the readability and attractiveness test of the Interactive Science Liveworksheets after being tested in the field. Data on the responses of educators and students to Interactive Science Liveworksheets oriented to higher-order thinking skills (HOTS) on heat and transfer materials were collected after the learning was completed. Respondents who were involved in finding out the educator's response to the Interactive Science Liveworksheets were one fifth grade educator at State Elementary School 6 Mataram who often used Liveworksheets during the online learning process in the new normal era.

Meanwhile, the number of respondents regarding the attractiveness and readability of the developed Interactive Science Liveworksheets was six respondents/students. The results showed that the response of educators to the use of Interactive Science Liveworksheets included in the category of practical use. The summary of the practical effects of product development trials is presented in Table 4.

Table 4. Recapitulation of Interactive Science Liveworksheets Practicality Score

\begin{tabular}{lcc}
\hline Instrument & Mean & Category \\
\hline $\begin{array}{l}\text { Teacher Response } \\
\text { Questionnaire }\end{array}$ & 3,69 & Very Practical \\
$\begin{array}{l}\text { Student Response } \\
\text { Questionnaire }\end{array}$ & 3,38 & Practical \\
\hline
\end{tabular}

\section{Dissemination Stage}

The dissemination stage focuses on disseminating the developed product, namely the Interactive Science Liveworksheets, which students can access at State Elementary School 6 Mataram and anyone who can access the live worksheets website to learn about the theme of heat and its transfer. Dissemination is carried out based on the validity and applicability tests results, which will then be submitted to partner schools.

\section{CONCLUSION}

Based on the results and discussion, it can be concluded that: 1) Interactive Science Liveworksheets oriented to higher-order thinking skills (HOTS) developed is declared valid with an average score of 3.33. 2) the level of practicality of the Interactive Science Liveworksheets oriented to higher-order thinking skills (HOTS) developed is in the criteria of 3.69 by educators and 3.38 by students. Based on these two things, the Interactive Science Liveworksheets oriented to higher-order thinking skills (HOTS) are valid and practical to be used in science learning at the elementary school level on heat material and its transfer.

\section{REFERENCES}

[1] Fadillah, N. Al. (2020). Empat Paradigma Pendidikan di Abad 21. Dinas Pendidikan Provinsi Jawa Barat.

[2] Hariadi, N., Rasmiwetti, R., \& Haryati, S. (2020). Pengembangan Lembar Kegiatan Peserta Didik Berbentuk Majalah Berbasis Berpikir Kritis Pada Materi Laju Reaksi Kelas XI Sekolah Menengah Atas. Jurnal Pijar Mipa, 15(5), 434.

[3] Aslan, S. (2015). Is Learning by Teaching Effective in Gaining 21st Century Skills? The Views of Pre-Service Science Teachers. Educational Sciences: Theory \& Practice, 15(6), 1441-1457.

[4] Chalkiadaki, A. (2018). A Systematic Literature Review of 21st Century Skills and Competencies in Primary Education. International Journal of Instruction, 11(3), 116.

[5] Farisi, M. I. (2016). Developing The 21stCentury Social Studies Skills Through Technology Integration. Turkish Online Journal of Distance Education, 17(1), 16-30.

[6] Ichsan, I. Z., Hasanah, R., Aini, S., Ristanto, R. H., \& Miarsyah, M. (2019). Higher Order Thinking Skills Assessment Based on Environmental Problem (HOTS-AEP): Mendesain Evaluasi Pembelajaran Abad 21. Jurnal Biotek, 7(1), 14-26.

[7] Sutrisna, N. (2021). Analisis Kemampuan Literasi Sains Peserta Didik SMA Di Kota Sungai Penuh. Jurnal Inovasi Penelitian, 1(12), 2683-2693.

[8] Pratiwi, I. (2019). Efek Program PISA Terhadap Kurikulum di Indonesia. Jurnal Pendidikan Dan Kebudayaan, 4(1), 51.

[9] Hewi, L., \& Shaleh, M. (2020). Refleksi Hasil PISA (The Programme For International Student Assesment): Upaya Perbaikan Bertumpu Pada Pendidikan Anak Usia Dini). Jurnal Golden Age, 4(1), 30-41.

[10] Habibi, H., \& Suparman, S. (2020). Literasi Matematika dalam Menyambut PISA 2021 Berdasarkan Kecakapan Abad 21. Jurnal Kajian Pendidikan Matematika, 6(1), 57-64. 
[11] Wulandari, E., \& Azka, R. (2018). Menyambut PISA 2018: Pengembangan Literasi Matematika Untuk Mendukung Kecakapan Abad 21. De Fermat: Jurnal Pendidikan Matematika, 1(1), 31-38.

[12] Angraini, G., \& Sriyati, S. (2019). Analisis Kemampuan Berpikir Tingkat Tinggi Siswa SMAN Kelas X di Kota Solok Pada Konten Biologi. Journal of Education Informatic Technology and Science, 1(1), 114-124.

[13] Saido, G. A. M., Siraj, S., DeWitt, D., \& AlAmedy, O. S. (2018). Development of an instructional model for higher order thinking in science among secondary school students: a fuzzy Delphi approach. International Journal of Science Education, 40(8), 847-866.

[14] Prasetyani, E., Hartono, Y., \& Susanti, E. (2016). Kemampuan Berpikir Tingkat Tinggi Siswa Kelas XI dalam Pembelajaran Trigonometri Berbasis Masalah Di SMA Negeri 18 Palembang. JURNAL GANTANG, 1(1), 31-40.

[15] Fanani, M. Z. (2018). Strategi Pengembangan Soal Higher Order Thinking Skill (HOTS) dalam Kurikulum 2013. Edudeena, 2(1), 5776.

[16] Gradini, E. (2019). Menilik Konsep Kemampuan Berpikir Tingkat Tinggi (Higher Order Thinking Skills) dalam Pembelajaran Matematika. Jurnal Numeracy, 6(2), 1892013.

[17] Syaifullah, M., \& Izzah, N. (2019). Kajian Teoritis Pengembangan Bahan Ajar Bahasa Arab. Arabiyatuna: Jurnal Bahasa Arab, 3(1), 127.

[18] Nurbaeti, R. U. (2019). Pengembangan Bahan Ajar IPA Berbasis Problem Based Learning Untuk Siswa Kelas V Sekolah Dasar. JURNAL CAKRAWALA PENDAS: Media Publikasi Pada Bidang Pendidikan Dasar, 5(1), 53-57.

[19] Fajri, Z. (2018). Bahan Ajar Tematik dalam Pelaksanaan Kurikulum 2013. Jurnal Pedagogik, 5(1), 100-108.

[20] Mardeni, P. R., Azmi, J., \& Linda, R. (2021). Pengembangan Lembar Kegiatan Peserta Didik (LKPD) Berbasis RMS (Reading, Mind Mapping, and Sharing) pada Pembelajaran Kimia. Jurnal Pijar Mipa, 16(1), 8.

[21] Nisrina, N., Jufri, A. W., \& Gunawan, G. (2020). Pengembangan LKPD Berbasis Blended Learning untuk Meningkatkan Literasi Sains Peserta Didik. Jurnal Pijar Mipa, 15(3), 192.

[22] Sulistyorini, S., Harmanto, H., Abidin, Z., \& Jaino, J. (2018). Pengembangan Lembar Kerja Peserta Didik (LKPD) Tematik Terpadu Mengintegrasikan Penguatan Pendidikan Karakter (PPK) dan Literasi Siswa SD di Kota Semarang. Jurnal Kreatif, 9(1), 21-30.

[23] Hasanah, N. (2019). Pengembangan Lembar Kerja Peserta Didik Berbasis Karakter. Jurnal
Pendidikan Dan Pembelajaran Terpadu, 1(1), 24-30.

[24] Munandar, H., Yusrizal, Y., \& Mustanir, M. (2015). Pengembangan Lembar Kerja Peserta Didik (LKPD) Berorientasi Nilai Islami Pada Materi Hidrolisis Garam. Jurnal Pendidikan Sains Indonesia, 3(1), 27-37.

[25] Dea Komalasari, M., \& Pardjono, P. (2016). Pengembangan LKPD Terintegrasi Nilai Karakter untuk Mengembangkan Tanggung Jawab, Disiplin, dan Prestasi Belajar Peserta Didik Sekolah Dasar. Jurnal Pendidikan Karakter, 1.

[26] Widiyani, A., \& Pramudiani, P. (2021). Pengembangan Lembar Kerja Peserta Didik (LKPD) Berbasis Software Liveworksheet pada Materi PPKn. DWIJA CENDEKIA: Jurnal Riset Pedagogik, 5(1), 132.

[27] Khikmiyah, F. (2021). Implementasi Web Live Worksheet Berbasis Problem Based Learning dalam Pembelajaran Matematika. Pedagogy: Jurnal Pendidikan Matematika, 6(1), 1-12.

[28] Thiagarajan, S., Semmel, D. S., \& Semmel, M. I. (1974). Instructional Development for Training Teachers of Exceptional Children: A Sourcebook. Leadership Training Institute/Special Education.

[29] Kusumah, R. G. T., Walid, A., Sugiharta, I., Putra, E. P., Wicaksono, I., \& Erfan, M. (2020). Construction of High School Chemistry Module, Based on Problem-based Learning (PBL) on Salt Hydrolysis Material for Gifted Students. Journal of Physics: Conference Series, 1467, 012047.

[30] Sugiyarto, K. H., Ikhsan, J., \& Lukman, I. R. (2018). The use of an android-based-game in the team assisted individualization to improve students' creativity and cognitive achievement in chemistry. Journal of Physics: Conference Series, 1022, 012037. 